\title{
A Thing About Machines: Eça de Queirós's Technological Twilight Zone
}

\author{
ANA ILIEVSKA \\ University of Chicago
}

\begin{abstract}
By reconstructing the acts and voices of technological artifacts in $A$ cidade e as serras (1901), this paper outlines what I call Eça de Queirós's technological "twilight zone," where machines are granted literary citizenship, and human interlocutors are forced to reevaluate who and what counts as humanity and conversation. I argue that the unresponsiveness of technological artifacts to the human voice in $A$ cidade $e$ as serras reveals a process of destabilization of power hierarchies and vocal anthropocentrism. Eça neither demonizes nor glorifies machines; rather he elaborates ways in which productive coexistence and communication can remain a prime objective. In A cidade e as serras, Eça parses out anxieties about technology and modernity in subtle and balanced ways that can shed new light on enduring questions about humanmachine interactions in our era of technological dependence.
\end{abstract}

Keywords: Artifacts, noise, voice, A cidade e as serras, Portuguese novel

Sometime in 1960, Bartlett Finchley (expertly played by the British comic actor Richard Haydn) would witness the unusual coming-to-life of his domestic appliances. ${ }^{1}$ A wealthy misanthrope intolerant of insubordination, he already had

\footnotetext{
${ }^{1}$ I would like to thank Dain Borges, Jennifer Iverson, Armando Maggi, Victoria Saramago, and Itamar Ramot as well as the participants and organizers of the 20th/21st Century and Sound and Society workshops at the University of Chicago for their invaluable comments on the first rough drafts of this essay. To Eric M. Gurevitch (University of Chicago) I owe the reference to David Arnold's book on everyday technologies, and to Vincent Barletta (Stanford) the noise reduction in my writing.
} 
trouble communicating with fellow human beings. But when his television turns on of its own accord and his clock continues striking the hour even after he smashes it to pieces, Finchley effectively loses all regard for any thing or being. The hatred is mutual, and in the end, Finchley's car self-drives him to his death, an act of defiant murder-suicide in a "realm where muscles and the will to fight back are not limited to human beings" ("A Thing About Machines"). The realm, that is, of The Twilight Zone.

Finchley's domestic devices belong to a genealogy of rebellious machines that pervade our technological imaginary-from Frankenstein's monster and Karel Čapek's robots to Stanley Kubrick's HAL 9000 and Ava in Ex Machina. The narrative seems always to be the same: humans create something, and then it turns against them. As readers and audience, we root for the machine that runs toward self-determinacy while condemning the often despicable, inconsiderate behavior of humans, and yet we seldom use this opportunity to reflect on our own day-to-day interactions with technological artifacts. We act, that is, as if technology were still a thing of the future.

In this essay, I take a step back from the future to study technology as a thing of the past. In search of alternative attitudes towards machines, I go back to the Second Industrial Revolution (1870-1914) in Europe, when human-machine relations reached an unprecedented level of complexity thanks to what David Arnold has called "everyday technology." At that time, technological artifacts began invading the household, day-to-day interactions, and literature alike. Soon enough, telegraphs, phonographs, and telephones became literary protagonists with a voice of their own. In this way, there began a conversation between voices of flesh and those of steel.

One can effectively employ José Maria de Eça de Queirós's A cidade e as serras to eavesdrop on this noisy conversation between humans and the technological "miúda legião" of European industrialization (Eça, A cidade 27). In reconstructing the acts and voices of technological artifacts in the novel, I outline what I call Eça's technological "twilight zone," where machines are granted literary citizenship, and human interlocutors are forced to reevaluate who and what counts as an interlocutor. I argue that the unresponsiveness of technological artifacts to the human voice in $A$ cidade $e$ as serras reveals a process by which power hierarchies and vocal anthropocentrism became destabilized at the end of the nineteenth century. Furthermore, against the double- 
edged sword of technophobia and boundless scientific enthusiasm in the nineteenth century (and our contemporary back-and-forth between aggressive technophilia and apocalyptic paranoia), Eça's model for human-machine interactions maps out a kind of middle ground that involves listening, care, and purposeful coexistence. A cidade e as serras ultimately neither demonizes nor glorifies machines; rather, it elaborates ways in which productive coexistence and communication can remain a prime objective. Such a rereading of Eça's final novel is not a critique of progress in favor of a rustic lifestyle, which is, in the end, little more than a clichéd dichotomy that serves to promote naïve Portuguese provincialism. ${ }^{2}$ It is, rather, a workshop on how to coexist with technological artifacts, a laboratory created by one of the masters of nineteenth-century prose fiction who knew industrialized centers like Paris and London well and was neither blind to the perils of scientific fanaticism nor to the pitfalls of nationalism. As I demonstrate, Eça subtly parses out anxieties about technology and modernity within this laboratory, and his balanced approach can shed new light on enduring questions about what is a "human" in our era of technological dependence.

Composed in 1900, and published posthumously in 1901, A cidade e as serras is an unpretentious novel with a very simple plot structure. ${ }^{3}$ Jacinto, the son of a Portuguese noble, grows up in Paris surrounded by all the comforts and inventions of the second half of the nineteenth century. He accumulates objects, books, devices, ideas, and friends from high Parisian society, firmly believing that the greatest happiness is but the (mathematical) product of the greatest knowledge multiplied by the greatest power. Jacinto spends half a lifetime and half of the novel pursuing the fulfillment of this metaphysical equation, "robustecendo a sua força pensante com todas as noções adquiridas desde Aristóteles, e multiplicando a potência corporal dos seus órgãos com todos os mecanismos inventados desde Terâmenes, criador da roda" (10). Having started

\footnotetext{
2 This was, however, the case with the short story "Civilização" (1892) that served as the foundation of the novel. According to Piwnik, "Civilização" is "essencialmente uma crítica dos efeitos do progresso, contrastando com o elógio da vida rústica" (20).

${ }^{3}$ Because of this, the novel has been indeed somewhat underappreciated by critics. Frank Sousa, for example, argues that "em geral esta obra tem sido vista como uma das menos interessantes, senão mesmo a menos interessante, do ponto de vista estético, em toda a novelística queirosiana" (9). Abel Barros Baptista reminds us that João Gaspar Simões, one of the most prominent scholars of Eça's work, "acusou $A$ cidade e as serras de insinceridade: Eça, argumentava o crítico, nunca trocaria Paris por Tormes" (44).
} 
with a few collected works and a telescope, Jacinto eventually ends up owning a vast library of some thirty thousand volumes and, "por sobre peanhas e pedestais, toda uma Mecânica sumptuosa, aparelhos, lâminas, rodas, tubos, engrenagens, hastes, friezas, rigidezas de metais" (26). But he learns nothing and creates nothing in this first "technological" part of the novel, for he has no other ambition "além de compreender bem as Ideias Gerais" (7). Unsurprisingly then, Jacinto fails to achieve happiness in the French capital. While he loses himself in endless yawns and boredom, his body and mind deteriorating among the lush comfort of his palace at Champs-Elysées No. 202, his machines begin to rebel and disobey. They create something of their own ecosystem comprised of wires, tubes, and cables spread all over the palace among dark laurel green carpets, wallpapers, and cushions, reaching up to the ceiling and disappearing through the roof into space (29). Spurred on by Zé Fernandes, a rustic and patriotic companion who also serves as the novel's first-person narrator, Jacinto decides to return to Portugal. Thus begins the second, "pastoral" part of the novel, which takes place in the rural Douro Valley. Jacinto moves into an old family castle in the beautiful but secluded mountain village of Tormes, and having lost all of his luggage and civilizational comforts during the train ride, he finds peace in simplicity, farm work, and a rosy-cheeked Portuguese wife. With this, civilization, technology, and the city seemingly lose the battle for Jacinto's body and soul. Nature and the agrarian, provincial, but ultimately fulfilling Portuguese countryside emerge triumphant. But is it as simple and black-and-white as that?

A careful reading of the novel reveals that it is filled to the very last page with the most diverse collection of things, objects, machines, and devices. This complicates the idea of a purportedly simplistic pastoral resolution to the plot and reveals, against the superficial moral of the novel, a fascination with technology. The sounds and noises of France and Portugal, of humans and machines alike, emanate from the pages of $A$ cidade $e$ as serras, both from the first "technological" and the second "pastoral" part, as if cut into vinyl. Throughout the novel, human and nonhuman protagonists interact in a fierce struggle to be heard, invading each other's stories and spaces, but also searching for a common ground and language. Let us now look at some of these interactions by reconstructing first the "acts of artifacts" within the novel (Verbeek 147).

\section{The Acts of Artifacts or, On Disobedience}


From the very first page, $A$ cidade e as serras is a ragbag of things. Eça presents these things in three sets, each coupled with a human interlocutor: Jacinto's jovial grandfather, the "gordíssimo e riquíssimo" Dom Galeão; Jacinto’s shadow-like and inconspicuous father, Jacintinho; and finally, Jacinto himself. As for the first, one day in the early1820s, while walking down a street in Lisbon, Dom Galeão slips on an orange peel and lands flat on his back. As luck would have it, the crown prince, Dom Miguel, was then passing by and stops to help the older man up. From that moment, Dom Galeão begins to adore "[o] seu salvador," and he soon hangs the latter's portrait in his home, just above "a bengala que as magnânimas mãos reais tinham erguido do lixo" (2). When the prince is sent into exile, Jacinto's grandfather reacts dramatically: "correu pela casa, fechou todas as janelas como num luto" (3). Not long afterward, he decides to go into voluntary exile in support of his "savior." The sea/land journey is disastrous: the ship struggles on rough waters, a coach axle snaps, the members of the noble family must knock "como mendigos a portas mudas" (4) in search of shelter, and they end up sleeping on tavern benches. The family moves into a Paris hotel, but a fire breaks out that leaves Dom Galeão at his wit's end and with his foot bleeding from a glass shard. He then impulsively buys an opulent palace at the Champs-Elysées 202, to take refuge "de tantas agitações" (5).

A sneaky orange peel, a runaway cane, a treacherous coach axle, reticent doors, and a malicious glass shard. Among all these objects, an entire family has uprooted its existence and moved from one country to another. All these disobedient things combine to create a sense of swift forward motion within the first few pages of the novel. Eça admittedly brings them to the fore for comical effect; however, in doing so he reveals an acute sense for the productive interrelatedness of human and nonhuman agents. In this he was quite unlike his intellectual father, Émile Zola, who saw in such relations only a recipe for disaster.

In Paris, Jacinto's father, the sickly offspring of Dom Galeão, becomes the lead character for about a paragraph and a half. He is characterized as a "moço mais esguio e lívido que um círio, de longos cabelos corredios, narigudo, silencioso, encafuado em roupas pretas, muito largas e bambas" (5). If Dom Galeão was a sturdy, loud, and somewhat grotesque Portuguese man who slips on orange peels and befriends princes, his son is a wallflower in a badly lit room. 
Cintinho does not avail himself of the objects that surround him; on the contrary, they avail themselves of him. The servants call him "a Sombra," given that he wanders the palace at night in his nightshirt, a candle in his hand, always silent, always in the background, as if he were a thing himself. The only active involvement he has with things and matter is an interest that he develops in woodturning: a circular (both mechanically and conceptually), nonconsequential activity that seems to say more about the wood than Cintinho.

The "silent shade" finally marries the daughter of a judge, and they have a son-although Cintinho does not live to see him born. The boy, Jacinto, is born in Paris with "a segurança, a rijeza, a seiva rica de um pinheiro das dunas" (6). Light and good fortune surround this child of the century of progress. His ideas are immediately accepted and applauded, his presence coveted. He is even "servido pelas coisas com docilidade e carinho" (8). Fortune, knowledge, nature, and things, Wissen and Können, "técnicos [e] filósofos" (10), all constitute a kind of Heideggerian standing-reserve for him - available, calculable, orderable. If glass shards pierced Dom Galeão's bare foot, coach axles snapped under his obesity, and things were unaffected by Jacintinho's existence, not even buttons pop off Jacinto's shirts, nor do pieces of paper dare hide from his gaze, nor perfidious drawers jam when challenged by his haste and vivacity. Eça first gives his reader a man, then a shadow, and then a super-man who effortlessly enjoys the fruits of civilization. Decisively, each one of these characters reveals himself to the reader through his respective relation to things and not to humans. Jacinto's palace is, after all, civilization armed to the teeth with things: a telegraph, a telephone, a theater phone, a conference phone, a phonograph, a typewriter, a calculator, and "uma estranha e miúda legião de instrumentozinhos de níquel, de aço, de cobre, de ferro, com gumes, com argolas, com tenazes, com ganchos, com dentes" (27). Jacinto is this legion's supreme commander. He is the Beast enchanted by Civilization, the factory owner served by his machines as if by a loving, albeit mischievous, army that slowly develops agency and begins to disobey.

Soon enough, as if coming to consciousness, the devices begin to resist the cheerful master-slave dynamic. The telegraph is described as an "aparelho esperto e diligente" (28), a little busybody spitting out long pieces of paper full of information. Other technological artifacts begin to sting and prick when picked up in the hand, "às vezes magoam, ferem [...]. Já me sucedeu inutilizar cartas 
por as ter sujado com dedadas de sangue," Jacinto confesses to Zé Fernandes (35). In a "rebelião da água," pipes burst and flood the entire palace in a deadly conspiracy with "fios dos lumes elétricos [que] sulc[am] faíscas ameaçadoras" causing a sensation in Paris (54). "[S]e havia mortos?" a reporter inquires on the staircase. “[E]sta nossa indústria! [...] Que impotência, que impotência!” a grayfaced Jacinto concludes (55). One evening, the electric lights suddenly all go out, throwing tantrums like a spoiled child, only to resume service a moment later, "como serva ralaça que recolhe arrastando as chinelas" (67). The phonograph similarly refuses to render its services: "[...] o Fonógrafo trabalha mal. Nem trabalha! Tenho três. Nenhum trabalha!” (78). Finally, during a dinner with prominent guests - the comic apogee of the novel - the dumb waiter gets stuck halfway between floors, with the main dish trapped inside. Jacinto and his guest of honor, the Grão-Duque Casimiro, torture and tug on the complicated machinery, but the lift remains unresponsive "numa inércia de bronze eterno" (90). No. 202's technological artifacts act and riot, all but coming to life and pushing Jacinto out. Why? What is the conflict between human and nonhuman entities that the anthropomorphizing description of technological devices reveals?

If we look at the metaphors and similes that Eça uses to describe the acts of technological artifacts and their interactions with humans in the novel, a semantic field of slavery and servitude emerges: machines are like laggardly servants; they summon Jacinto as if summoning a tardy slave, "escravo tardio" (44); servants fumble around devices and around Jacinto who fumbles around machines and summons servants in an intricate network of master-slave relations - all this for the sake of the "simplificação que dão ao trabalho" (35). It is in this sense that Giorgio Agamben, building on Hannah Arendt's distinction between work and labor in chapter three of The Human Condition, notes that "slavery was to the ancients what technology is to the moderns" (111), and the two worlds are still interwoven in Eça's novel. Agamben asks whether there is not something more at stake in these two sets of interactions than the mere simplification of work by the slave/machine. Slavery released the Greeks from necessity, he writes, and it also assured them undisturbed access to political life. Machines, on the other hand, allow modern humans to dominate the forces of nature while simultaneously obviating the need for any human element in between. In $A$ cidade e as serras, one sees this idea of taming nature through technology clearly 
expressed in the words of Zé Fernandes: "Todos [os aparelhos de Jacinto] mergulhavam em forças universais, todos transmitiam forças universais. A Natureza convergia disciplinada ao serviço do meu amigo e entrara na sua domesticidade!" (29f). But Jacinto's technological artifacts do not help him tame Nature. On the contrary, they expose the uncontrollable forces that lie within them, ready to erupt and destroy their user as a response to the slightest mismanagement or misuse. They also expose a new element in the relationship between human and nonhuman entities that is not present in the master-slave configuration, namely, indifference:

E de repente, revoltado contra este fastio opressor que o escravizava, [Jacinto]saltou da poltrona com um arranque de quem despedaça algemas, e ficou ereto, dardejando em torno um olhar imperativo e duro, como se intimasse aquele seu 202, tão abarrotado de Civilização, a que por um momento sequer fornecesse à sua alma um interesse vivo, à sua vida um fugitivo gosto! Mas o 202 permaneceu insensível: nem uma luz, para o animar, avivou o seu brilho mudo: só as vidraças temeram sob o embate mais rude de água e vento. (161-62)

The machine is indifferent to "um olhar imperativo e duro," as well as to pain, punishment, orders, shame, urgency, and discipline. In other words, it is indifferent to power relations, and it is not obliged to aid humans in any way, unless we specifically program it to do so.

Compared to human servants, machines thus appear dangerous and even hostile, for they are impervious to commands and have no fear of a flesh-andbones master. A cidade e as serras foregrounds this new relationality, one that ultimately leaves modern humans to our own devices. For the master, it is no longer enough to rely on a servant or a domestic animal for the fulfilment of one's needs, nor it is possible to substitute these with a machine that appears to have a will of its own. Jacinto is invited to participate actively in the world, with his own bare hands, but he does not have the necessary skills for it. As the epitome of the saturated and spoiled aristocrat accustomed to blind obedience, Jacinto hoards books and devices rather than reading and/or employing them to achieve higher (political or other) goals. If he has any desire to dominate the forces of Nature, it 
is out of hedonism. When Jacinto comes face-to-face with what he and Zé Fernandes perceive to be the intentional hostility of the new and inscrutable legion of steel servants, he retreats into melancholy, silence, yawns, murmurs, and, ultimately into physical degradation. Jacinto and Finchley might try to torture their devices, pull their cables, smash them against the wall, and kick in their screens, but the devices remain unmoved. The latter's disobedience exposes the solitude and fecklessness of modern humans, who have for too long relied on the labor of others for the fulfilment of their needs.

In The Twilight Zone, the resolution of this unsustainable dynamic between humans and machines results in Finchley's death. In Eça's novel, it purportedly ends with Jacinto's seclusion from the civilized world and escape from technology. But let us not get ahead of ourselves. There is, after all, a further defining element of the relation between Jacinto and his technological devices that needs to be taken into consideration: the interplay of the human voice and the machine's noise. According to Arendt, speech and action together are what make the human condition unique: "with word and deed we insert ourselves into the human world" (176). She goes on to argue that we announce our unique presence and personal identity to others "in sheer human togetherness" (180). I propose that we expand this characterization of humanity to include nonhuman entities and rephrase it in a way that might account for the acts and voices of artificial intelligences as well. This is necessary if we are to understand better the complex human-machine relationships that pervade our imaginary and our lives.

\section{The Voices of Artifacts or, On Noise}

Engineers working on human-machine interactions by voice in the twentieth and twenty-first centuries have recognized something very basic about the human voice: it is by far the most popular and simple means of communication used by humans. In fact, it comes so naturally to us to "do things with words," as John L. Austin's famous formula goes, that we even talk to our machines and would find it much easier simply to tell them what to do by voice than sit down, open up our laptops or unlock our phones, type in a request, and wait for a result. It is for this reason that researchers and tech companies are making continuous attempts to enable and perfect human-machine communication by voice command alone (Ronald W. Schafer). For millennia, humans have existed in an absolute 
anthropo-voco-centrism that allows us to command other human beings and animals as sources of labor. With the Industrial Revolution, however, machines joined this labor inventory, disrupting vocal anthropocentrism. When machines first brought a swelter of confusion onto the European continent in the nineteenth century, they could not hear and could therefore not listen/obey in the traditional sense. They made plenty of noise, they could capture and replay the human voice, and they interfered with human speech and accepted notions of what is musical and sonically welcome. With all this, however, they remained essentially unmoved by vocal directives. For the most part, little has changed. Unless we own an extremely sophisticated device or press a button, our phones will not move an inch, nor will they execute most of what we tell them to do. The slaves of antiquity might have been called instrumentum vocale or "speaking instruments," as Arendt notes (121), but they did not have a voice in any political and participatory sense, nor could they simply shut their ears and choose not to hear and therefore disobey their masters' commands. Arendt here underestimates the subversive power of what she refers to as "mute robots" (121). In short, she undervalues the subversive power of mechanical silence and noise; machines continue to be largely unresponsiveness to our voice commands, while we constantly seek to silence and suppress the noise they emit.

Writing on Charles Baudelaire's "poetics of noise," Ross Chambers speaks of the destructive power of "noise as entropy, the danger of erosion and eventual erasure that means the death of the self" (11). Noise is "the murderer of thought," Arthur Schopenhauer famously quipped, adding that it "is the most impertinent of all interruptions, for it not only interrupts our own thoughts but disperses them" (642-43). Scholarship abounds on these "unwanted sounds" or noises, and on the efforts to which human beings and governments have gone in order to contain, discipline, and domesticate them. ${ }^{4}$ In Eça's technological twilight zone, however, malfunctioning and noise are the ways in which the machine announces its presence to the world and challenges anthropocentrism. It superimposes its own noisy existence onto the human one, destabilizing power hierarchies that

\footnotetext{
4 "Noises are the sounds we have learned to ignore," writes R. Murray Schafer (3). In his glossary, he lists four definitions for "noise" and concludes: "Of the four general definitions [unwanted sound, unmusical sound, any loud sound, disturbance in any signaling system], probably the most satisfactory is still 'unwanted sound"' (183).
} 
predetermine who can become a protagonist and have a voice in literature and society alike.

Technological artifacts dominate the soundscape of the first half of $A$ cidade e as serras, while humans lose themselves in murmurs, yawns, and silence. Zé Fernandes describes Jacinto's "estranha e miúda legião de instrumentozinhos" as being expressive ("expressivos todos" 27). The telegraph's "tic-tic-tic" is "açodado, quase ansioso" (27). Other devices have mouths gaping towards the voices of the universe; the conference phone gives out a "zumbido, como de um inseto de azas harmoniosas" (31); and the voice that comes out of it is an opportunist, "aproveitando da [...] curiosidade [do Zé Fernandes] para [o] invadir e se apoderar do [s]eu entendimento" (32). The telephone bell calls for Jacinto "como por um escravo tardio" (44), constantly spreading its "insaciável" sonic tyranny (56). A silvery and melancholic "tam-tam" summons the two men to lunch (45); and "roncos surdos no interior das paredes" (54), both threatening and indifferent, announce the plumbing catastrophe. During the same dinner marred by the dumb waiter incident, the phonograph refuses to render its services to the party. The humans then gather around the theater phone, a device directly connected to the lyric opera: "De cada orelha atenta, que a mão tapava, pendia um fio negro, como uma tripa" (83). In this way, the guests merge with the machine's organs and surrender themselves to the transmission, "como se o fio lhe murmurasse doçuras" (83). They listen to the prima donna's aria "por debaixo do solo de Paris, através de fios mergulhados nos esgotos, cingidos aos canos das fezes" (84). But nothing comes through clearly, and the Grão-Duque eventually exclaims: “-Não se ouve nada! Só guinchos! E um zumbido! Que massada!" (85). For a moment, the machine forces the guests to stop and listen to ambient sounds; however, these guests cannot maintain the requisite silence and attention, used as they are to issuing orders and commands. As more and more technological accidents happen in the residence, Jacinto responds by accumulating even more mechanical artifacts. The result is a cacophony: "nessas semanas de abril, enquanto as rosas desabrochavam, a nossa agitada casa [...] incessantemente tremeu [...] com o bruto picar de pedra, o retininte martelar de ferro" (99).

Machines emerge from these passages as the most vociferous inhabitants of Champs-Elysées No. 202, while their purported human master gradually loses his voice. The sounds of Jacinto's footsteps vanish, absorbed by the somber 
carpets; his commands remain unheard, and his speech becomes increasingly inarticulate. In fact, the novel by this point becomes saturated by Jacinto's "murmurs." In just the first half of the novel, the narrator employs the verb murmurar and its variants forty times to describe human utterances. In contrast, the novel's machines are expressive and diligent. In fact, if one were to construct and record the soundtrack of $A$ cidade e as serras, the human voice would be all but absent under the multiple layers of noise.

In Eça's novel, machine noise is present on the descriptive level through its onomatopoeic rendering "tic-tic-tic," "tam-tam," etc. At the same time, the noise of machines interrupts human conversations, ruins dinner plans, summons servants and guests alike, and drives human protagonists into silence. All this strongly suggests a deeper involvement in the plot and narrative. These mechanical noises, in other words, are not just part of the novelistic soundscape; they interfere with conversations and intervene in scene resolutions, creating depth within the fictional world, and ultimately breaking through the surface of mere description. Such agency implies more than just an ornament; it frames machines as fictional protagonists possessing, if not a language, at least a voice capable of disrupting the monologic nature of the human voice. With this, they complicate if not alter the structures of communication in the novel, claim our attention, and call for alternative modes of relationality against a blind anthropocentrism rooted in exploitation and irreverence for other forms of existence. "All right. All right, you machines. You're not going to intimidate me! Do you hear me?!" Finchley demands to know, infuriated, after having smashed half of his machines to pieces and alienated the few human beings remaining in his life. "Do you hear me?!" The thing about machines is that they do not.

\section{In Search of a Middle Ground}

In his analysis of Nathaniel Hawthorne's Notebooks (1844), Leo Marx underscores the progression underlying the former's account of his own sense perception. Hawthorne begins with a description of the sounds of the natural environment, he moves to the "sounds of [human] labor," and he ends by describing the sudden, shrieking, and harsh sound of a locomotive. The sounds of nature and of human society hardly draw our attention, Marx writes, "[b]ut the disturbing shriek of the locomotive changes the texture of the entire passage. 
Now tension replaces repose, for the locomotive's noise arouses a sense of dislocation, conflict, and anxiety" (16). The machine represents "the intervention of reality" into the idealized landscape (23), a force that dissolves such dichotomies as city versus countryside, civilization versus nature, and vision versus sound. Major nineteenth-century American writers responded to mechanical interruption with the pastoral ideal - a "semi-primitivism located in a middle ground somewhere 'between,' yet in a transcendent relation to, the opposing forces of civilization and nature," and always in a "serene partnership with Nature" (Marx 23).

Two conclusions emerge from Marx's analysis, with productive implications for a critical understanding of Eça's technological twilight zone. In the first place, the pastoral ideal outlined by nineteenth-century American writers is compatible with the solution offered by Eça in $A$ cidade $e$ as serras, but only with some qualifications. In the second half of the novel, Jacinto travels by train from Paris to Tormes, loses his luggage on the way, and arrives in the Douro Valley without servants or any of the complicated machinery he had packed to bring "civilization" to the mountains. He is initially terrified at the prospect of a solitary, rustic lifestyle. Slowly, however, he begins to shed his many layers of modernized skin. He first regains his voice. Zé Fernandes makes a point of characterizing his friend's utterances as "cries," "roars" and "shouts" rather than the "murmurs" that dominate the first part of the novel. Jacinto then begins to contemplate and listen to the sounds of nature. He finally rejects Schopenhauer and other urbane pessimists and begins to interact with the local workers, peasants, and children. He chooses to read only Miguel de Cervantes's Don Quijote and (like the Jacinto of "Civilização") begins to lead a simple life devoid of any modern technology. The lost crates from the train journey from Paris to Tormes eventually reappear, but Jacinto decides to keep only the bare necessities: rugs for the bare floors, curtains where needed, and an armchair for the comfort of his wife.

Jacinto quickly follows his first, largely contemplative phase in Tormes with a desire to act. This perhaps unsurprisingly leads him to hatch a plan to alter the landscape by building a factory in the mountains. But moving a mountain is easier said than done. Moved by the miserable conditions in which his own workers and peasants live, Jacinto finally decides to construct houses, a pharmacy, a school, a kindergarten, a projection room, and a library for them, 
raise their payments, and bring a doctor to the mountains. He plants, saws, works, and becomes completely integrated into the community, now with concrete goals in mind to such a degree as to declare himself a socialist, explaining "que socialista era ser pelos pobres" (335). Jacinto, as René de Costa has noted, begins to "create significantly" (78). He now has a purpose and has moved from an exploitative mode to a poetic one, regaining his capacity to feel awe and wonder before the landscape, the people, and the objects that surround him.

Jacinto's semi-primitivism resembles that about which Arthur O. Lovejoy, Hawthorne, and Marx have also spoken; however, this is not where the novel ends. For Eça, it is not enough for Jacinto to transition from civilizational clutter to a kind of pastoral minimalism, from a life of accumulation to a life of implementation aided by workers and tools. It is only when the little technologies reenter Jacinto's life in the mountains, when Jacinto "entreabr[e] a porta de Tormes à Civilização" (352), when he goes from being a commander to an interlocutor, that the novel reaches a point of resolution. In 1892, Eça had rejected any communion between man and machine in "Civilização," leaving the protagonist with an "honesto mínimo de civilização que consiste em ter um teto de colmo, uma leira de terra e o grão para nela semear [...] sem fonógrafo e sem telefone" (247-49). Only eight years after writing "Civilização," and while living amid all the noise and technological invention of Paris, Eça revised his position and outlined a much more viable solution to the tensions arising from humanmachine relations. ${ }^{5}$ Jacinto, in fact, installs a telephone line to his father-in-law's house and leaves the device to "subtilmente, mudamente, estende[r] outro longo fio" (353) to the doctor's and finally to Zé Fernandes's house, while Zé Fernandes reassures the villagers that "essa máquina nem fazia barulho, nem trazia doenças, nem atraía as trovoadas" (353). Eça's resolution thus rejects the grim outlook of Zola, and subsumes the semi-primitivism of the American Romantics, proposing a kind of middle ground between Jacinto's early technophilia and other, more Luddite stances. The entire second part of $A$ cidade $e$ as serras is oriented, in fact, to making a decent human being of Jacinto. Only when this "perfeição da beleza moral" (351) of the main character is achieved, do the machines reenter the narrative - and now not as an army employed by

\footnotetext{
${ }^{5}$ Here I agree with António Feijó, who argues that "o romance foi escrito contra o conto" (34).
} 
Jacinto to discipline and domesticate the forces of nature, but as connectors that build bridges between humans, nonhumans, and the environment.

Also important is the question of sound. While Marx correctly points out the ubiquity of sound in Hawthorne's diary, speaking even of "auditory images" (28), he stops short of addressing its full implications. A closer reading of Hawthorne's account reveals that it is not birds or clockmakers or the train locomotive that appear suddenly (perhaps almost magically) in the landscape and the writer's perception - it is their sounds. This is how the world announces itself, human and nonhuman alike. Long before we catch sight of a bird or of a train, their sounds and noises have reached us already. Synecdoche aside, why then an insistence on "the image of the machine's sudden appearance in the landscape" as the pivotal moment? (Marx 16, emphasis my own). Sounds evoke images; however, even before this the noise of the machine serves as an acoustic slap in the face. Through the interruption of the locomotive's whistle, Hawthorne wakes from his idealized, idyllic dreamworld and returns to reality. He is made aware that it was art in the first place - and I believe that Marx has techne in mind when he uses this term - that "has designed the symbolic landscape in which the industrial technology makes its appearance" (Marx 18). The locomotive's whistle reminds us that there is no such thing as a tripartition between a natural, human, and technological world. There is just environmentality, coexistence, and circumspection; and for this reason, there should be care (Heidegger 95-107; Morton). The train, with its deafening noise (an unprecedented sonic phenomenon in the nineteenth century) and Jacinto's rebellious technological artifacts bring about this awareness when they "pre[ss] [their] messages on attentive auditors" (Daston 12). They superimpose their noises onto the human voice in the first part of $A$ cidade e as serras, reducing anthropo(-voco-)centrism to a literal murmur. Theirs is a wake-up call that announces the presence of other beings with agency and voices of their own that resist master-slave relations and call for a reconfiguration of the ways in which humans relate to other beings and to the world.

With an ending that leaves the door to technology ajar, Eça's novel serves as a manifesto and warning par excellence against a technological mode of existence (instrumentalization, utilitarianism), but not against technology itself. He first conjures up of the powerful, disruptive capacity of mechanical voices to challenge vocal anthropocentrism and then brings human beings and machines 
into meaningful networks of interaction. Unlike Honoré de Balzac's minute attention to the qualities and names of objects, and Zola's "thingifying" of everything nonhuman into a sinister brutal beyond, Eça proposes an attitude towards machines that at first might resemble a simple escape to anthropomorphism. Upon a second look, however, a much more complex twilight zone of human-nonhuman relations emerges in which artifacts possess agency and voice. Their constant disobedience in the first part of $A$ cidade e as serras is a rebellion against civilizational clutter and the mindless accumulation of and dependence on technological devices. Their purposeful reintroduction as interlocutors and mediators in a network of relations in the second part of the novel-after the human protagonist has undergone a significant moral transformation - is a call for coexistence that promotes technological literacy above all. Reread in this light, $A$ cidade e as serras emerges as a technological Bildungsroman that destabilizes the certainties of anthropocentrism. It ultimately shows how it is not technology that poses a threat to humanity but rather devious human masters who continue to tilt at windmills that have long been the object of deconstruction in literature's twilight zone.

\section{Works Cited}

2001: A Space Odyssey. Directed by Stanley Kubrick, Metro-Goldwyn-Mayer, 3 Apr. 1968.

Agamben, Giorgio. L'uso dei corpi. Homo Sacer, IV. Neri Pozza, 2014.

Arendt, Hannah. The Human Condition. 1958. U of Chicago P, 1998.

Arnold, David. Everyday Technology: Machines and the Making of India's Modernity. U of Chicago P, 2013.

"A Thing about Machines." The Twilight Zone, directed by David Orrick McDearmon, written by Rod Serling, season 2, episode 4, CBS Broadcasting, 28 Oct. 1960.

Austin, John L. How to Do Things with Words. Clarendon, 1962.

Barros Baptista, Abel. "Por via postal." A cidade e as serras: uma revisão, edited by Abel Barros Baptista, Angelus Novus, 2001, pp. 44-53.

Čapek, Karel. R.U.R. (Rossum's Universal Robots). 1921. Translated by Claudia Novack, Penguin, 2004. 
Chambers, Ross. An Atmospherics of the City: Baudelaire and the Poetics of Noise. Fordham UP, 2015.

Costa, René de. "The Mythic Quest Theme in A cidade e as serras." LusoBrazilian Review, vol. 5, no. 2, 1968, pp. 71-79.

Daston, Lorraine. Things that Talk: Object Lessons from Art and Science. Zone Books, 2004.

Eça de Queirós, José Maria de. A cidade e as serras. 1901. Edited by Helena Cidade Moura, Livros do Brasil, 1969.

-. Cartas da Inglaterra e Crônicas de Londres. 1900. Livros do Brasil, 2001.

-. "Civilização." 1892. Contos I, edited by Marie-Hélène Piwnik, Imprensa Nacional Casa da Moeda, 2009, pp. 225-49.

Ex Machina. Directed by Alex Garland, Universal Pictures International, 12 Apr. 2015.

Feijó, António M. “O drama de Émile Aulard.” A cidade e as serras: uma revisão, edited by Abel Barros Baptista, Angelus Novus, 2001, pp. 33-41.

Heidegger, Martin. Being and Time. 1927. Translated by John Macquarrie and Edward Robinson, Harper Perennial, 2008.

Lovejoy, Arthur O. A Documentary History of Primitivism and Related Ideas. Johns Hopkins UP, 1935.

Marx, Leo. The Machine in the Garden: Technology and the Pastoral Ideal in America. 1964. Oxford UP 2000.

Morton, Timothy. "Frankenstein and Ecocriticism." The Cambridge Companion to Frankenstein, edited by Andrew Smith, Cambridge UP, 2016, pp. 143-57.

Piwnik, Marie-Hélène. "Introdução to Contos I." Edited by Marie-Hélène Piwnik, Imprensa Nacional Casa da Moeda, 2009, pp. 15-32.

Schafer, R. Murray. The Soundscape: Our Sonic Environment and the Tuning of the World. Destiny, 1977.

Schafer, Ronald W. "Scientific Bases of Human-Machine Communication by Voice." Proceedings of the National Academy of Sciences of the United States of America. vol. 92, no. 22, 24 Oct. 1995, pp. 9914-20.

Schopenhauer, Arthur. "On Din and Noise." Parerga and Paralipomena: Short Philosophical Essays, vol 2, translated by E.F.J. Payne, Clarendon P, 1974, pp. 642-44.

Shelley, Mary. Frankenstein or, The Modern Prometheus. Lackington et al., 1818. 
Ilievska

Sousa, Frank F. O segredo de Eça: ideologia e ambiguidade em A cidade e as serras. Cosmos, 1996.

Verbeek, Peter-Paul. What Things Do: Philosophical Reflections on Technology, Agency, and Design. Pennsylvania State UP, 2005. 